\title{
自己免疫性肝疾患，とくに原発性胆汁性肝硬変症と 慢性活動性肝炎重複症例に出現する新しいマーカー抗体
}

宮地 清光・鷹野 佐恵子 - 松 嶋 広
樋渡 恒憲・唐沢 英偉*.三 木

Jpn. J. Clin. Immun., 11(3):216 223, 1988.

\section{A new marker antibody (the MM antibody) for primary biliary cirrhosis-chronic active hepatitis overlap patient}

\author{
Kiyomitsu Miyachi, Saeko Takano, Hiroshi Matsushima, \\ Tsunenori Hiwatashi, Eii Karasawa* and Makoto Miki* \\ Autoimmune Disease Center, Health Science Research Institute \\ * National Yokohama Higashi Hospital
}

【Summary】

\begin{abstract}
An uncharacterized antibody was found in a patient afflicted with primary biliary cirrhosis or chronic active hepatitis. This antibody (which we tentatively called the MM antibody) could be detected by means of double immunodiffusion using the microsomal fraction of rat liver as the antigen. However, cytoplasmic staining in both rat liver and kidney could not be obtained when viewed by indirect immunofluorescent microscopy. The MM antibody did not react with mitochondrial fraction of rat liver. The antibody showed nonidentity with anti-liver kidney microsome antibodies when tested by means of double immunodiffusion. It was found in 5 of 5 PBC-CAH overlap patients who were diagnosed histopathologically, 3 of $19 \mathrm{PBC}$ patient sera and in 2 of $14 \mathrm{CAH}$ patient sera. However, it was not found in non-autoimmune hepatitis patients, nor in the healthy subjects. In conclusion, the detection of $\mathrm{MM}$ antibody might be useful for the diagnosis of autoimmune liver diseases particularly, PBC-CAH overlap patient.
\end{abstract}

Key words : $\mathrm{PBC}$,

CAH,

double immunodiffusion, MM antibody 


\section{【概 要】}

原発性胆汁性肝硬変症 (PBC) と慢性活動性肝炎 (CAH) の定型的重複症例 MM の血清中に未同定の自己抗体を発 見し，本抗体を MM 抗体と名付けた．本抗体はラット肝細胞質 3 分画を用いた二重免疫搪散 (DID) 法で検討すると ミトコンドリア分画と反応せず，マイクロゾーム分画と強く反応した。抗ミトコンドリア抗体陰性で MM 抗体陽性 血清を用いた間接螢光抗体法で検索すると，ラット肝，腎の細胞質に特異螢光は確認されなかった. DID 法では MM 抗体は抗 Liver Kidney Microsome 抗体と完全に交叉した. 本抗体の陽性頻度は肝生検で確認された PBC-CAH 重 複症例 5/5, PBC 3/19, CAH 2/14 に認められたが, 非自己免度性肝疾患, 正常人には検出されなかった. 本抗体は自 己兔疫性肝疾患, とくに PBC-CAH 重複症例の診断に役立つものと思われる.

\section{I. はじめに}

慢性活動性肝炎の原因には, B 型, non A non B 型, ア ルコール性, 薬㶡性の他，自己免疫性などが考えられて いる. 自己免疫性肝疾患には，免疫抑制剤がとくに有効 とされているので早期診断が必要である. 自己免疫性肝 疾患のマーカー抗体としては, 原発性胆汁性肝硬変 (primary biliary cirrhosis, PBC) の抗ミトコンドリア抗体 (anti-mitochondrial antibody, AMA) ${ }^{1,2)}$ やルポイド 肝炎に出現する抗平滑管抗体 (anti-smooth muscle antibody, ASMA) p) p抗核抗体 (anti-nuclear antibody, ANA）がある.さらに、ルポイド肝炎と異なる慢性活動 性肝炎 (chronic active hepatitis, CAH) k出現する抗 Liver Kidney Microsome (LKM) 抗体4,5)などが報告 されている. 抗 LKM 抗体住, halothene ( $^{6)}$ や tienilic $\mathrm{acid}^{7)}$ による薬剤性肝炎にも出現するといわれている が，本邦ではまったくその報告をみない，当研究所では PBC 㭧者血清の $20 \sim 30 \%$ に検出され, 従来の AMA と は異なり,ラット肝細胞質のマイクロジーム (Mic) 分 画とおもに反応する新しいマーカー抗体を発見した．定 型的 PBC-CAH 重複症例の患者 $\mathrm{MM}$ の頭文字をとり， $\mathrm{MM}$ 抗体と名付けた.ここに本抗体の臨床的意義, 頻度 について報告する.

\section{II. 対象および方法}

1. 対 象

対象は, PBC 19 例, PBC-CAH 重複症例 5 例, CAH 14 例, 肝癌 (HCC) 3 例, 肝硬変 (LC) 9 例, 急性 B 型 肝炎 (AVH) 5 例, 正常人 25 例とした. その他, 抗 LKM 抗体標準血清は Dr. Berg より分与された. 抗 r-RNP 抗体, AMA 標準血清は本研究所で同定されたものを使 用した。

PBC の診断は厚生省特定疾患「難治性の肝炎」調查研 究班自己免疫性肝炎分科会で作成された基準によった ${ }^{8)}$.
(1) 組織学的には chronic non-suppurative destructive cholangitis (以下 CNSDC) を認めるもの.

(2) AMA が陽性で, 組織学的には CNSDC の所見 を認めないが, PBC に矛盾しない (compatible) 組織像 を示すもの.

(3) 組織学的観察の機会はないが, AMA が陽性で, しかし臨床像，および経過から PBC と考えられるもの.

慢性肝炎の診断基準は, 1968 年のヨーロッパ分類に従 っ ${ }^{9)}$.

また, $\mathrm{PBC}$ と $\mathrm{CAH} の$ 重複症例の診断基準は，以下の ごとくI〜群に分別した ${ }^{10,11)}$.

I 群 : 症候性 PBC で CAH の診断基隻をむ満たした 重複例.

II 群: 病理組織学的には CNSDC の所見を呈し, AMA む陽性であるが, 臨床的には PBC の所見 (ビリ ルビン, Alp, コレステロールの上犁, 瘙凊感など)を欠 いている例.

III群: 病理組織学的に CNSDC と同時に CAH の所 見を呈し, AMA が検出されない. また, PBC としての 臨床的検查成績 (IgM, Alp, コレステロールの上昇など) を呈さない例とした.

\section{2. 組織抽出物の作製}

ラット肝からのミトコンドリア (Mit) 抗原, マイク ロゾーム (Mic) 抗原, 上清 (Sup) 抗原の抽出は Schneider らの方法 ${ }^{21}$ に従った. ラットを心採血によって放 血した後、肝䁍を摘出し, 血管や結合織を除去し，八サ ミで細切し， 9 倍量の $0.25 \mathrm{M}$ ショ糖液を加え, Potter 型ホモジナイザーで, 800 r.p.m. で 4 往復した. $700 \mathrm{~g}$, 10 分の遠心にて核成分を沈洀除去した. その上清から $5,000 \mathrm{~g}, 10$ 分の遠心にて得た沈渣を少量のシ $\exists$ 糖液で 洗浄し, $24,000 \mathrm{~g}, 10$ 分遠心し, 沈渣に $0.25 \mathrm{M}$ シ $\Xi$ 糖液 を加え，40秒の超音波処理をし，Mit 分画とした. 5,000 $\mathrm{g}, 10$ 分, $24,000 \mathrm{~g}, 10$ 分の上清を集め, $148,000 \mathrm{~g}, 30$ 
分の超遠心をして, 沈椬に $0.25 \mathrm{M}$ ショ糖液を加え, Mic 分画とした. $148,000 \mathrm{~g}, 30$ 分の上清は限外滤過法 にて濃縮し, Sup 分画とした.

\section{3. 抗体の検出法}

1) - 間接螢光抗体 (indirect immunoflorecence, IIF) 法

胃壁で包み込んだラット腎のクリオスタット切片 ( $\mathrm{MBL}$ 社) とラット肝のクリオスタット切片 (MBL 社) の基質を使用した. 5 倍および 20 倍希釈の被検血清でお おい, 45 分室温で反応後, PBS にて洗浄し, FITC 標識 antihuman IgGAM goat $\gamma$-globulin 応させた. PBS で洗浄し，90\% 無螢光グリセリン $(\mathrm{pH}$ 9.5) で封入し, 落射型螢光顕微鏡（オリンパス $\mathrm{BH} 2$ RFK）で観察した.

2) 二重免疫拡散 (double immunodiffusion, DID) 法 ${ }^{13)}$

$0.1 \% \mathrm{NaN}_{3}$ 加 PBS に溶解した 0.6\% アガロース（半 井化学) を直径 $90 \mathrm{~mm}$ のシャーレに $12.5 \mathrm{ml}$ ずつ分注 し, 平板を作製し, well の大きさは直径 $4 \mathrm{~mm}$ ，間隔は $3 \mathrm{~mm}$ とした. 試料は $20 \mu l$ ずつ分注し, 室温, 湿潤箱 中に放置し， 5 日間にわたって観察を続けた．抗体の同 定には，明瞭な沈降線を示す血清希釈倍数を求め，標準 血清にて検討した.

\section{4. 抗原の蛋白濃度の測定}

抗原の蛋白濃度は Lowry 法で行った ${ }^{14)}$.

\section{III. 成 績}

\section{1. 抗 $M M$ 抗体の特異性}

Mic 抗原を中心に拉き, MM 抗体, 抗 LKM 抗体, 抗 r-RNP 抗体を周囲におき, DID 法で検索した. その結 果, MM 抗体は 抗 LKM 抗体, 抗 r-RNP 抗体と異な っていた (図 1). 抗 r-RNP 抗体は Mit 抗原でも検出 されたが, MM 抗体は検索した条件下では認められなか
った.

\section{2. $M M$ 抗体のラット肝細胞質 3 分画との反応性}

表 1 に示したごとく, DID 法で MM 抗体と Mit 分 画抗原との反応では検出困難で, Mic 分画抗原の最終濃 度 $12.5 \mathrm{mg} / \mathrm{ml}$, Sup 分画抗原 $25 \mathrm{mg} / \mathrm{ml}$ で検出が可能 であった. 抗ミトコンドリア抗体との反応は, Mic, Sup 抗原では検出されず, Mit 抗原 $12.5 \mathrm{mg} / \mathrm{m} l$ で検出可能 であった. 抗 r-RNP 抗体は Mit 抗原 $6.25 \mathrm{mg} / \mathrm{m} l$, Mic 抗原 $1.56 \mathrm{mg} / \mathrm{ml}$, Sup 抗原 $25 \mathrm{mg} / \mathrm{ml}$ とで沈降線 を形成した（表 1).

3. ラット腎, ラット肝を基質とした $\mathbf{M M}$ 抗体の間 接螢光抗体法

AMA 陰性, MM 抗体陽性の患者血清（TF）を用い た検索では腎尿細管細胞は染色されなかった. しかし本 血清は, ASMA 陽性で, ラットの胃の粘膜筋板, 筋層, 血管壁が染色された. AMA 陽性血清 (MM) は他の AMA 陽性血清 (TT) と同様, 遠位, 近位尿細管細胞細 胞質がともに微細顆粒状に染色され, ASMA 陰性であっ た. 抗 LKM 陽性血清は近位尿細管細胞質が特異的に染 色された（図 2).

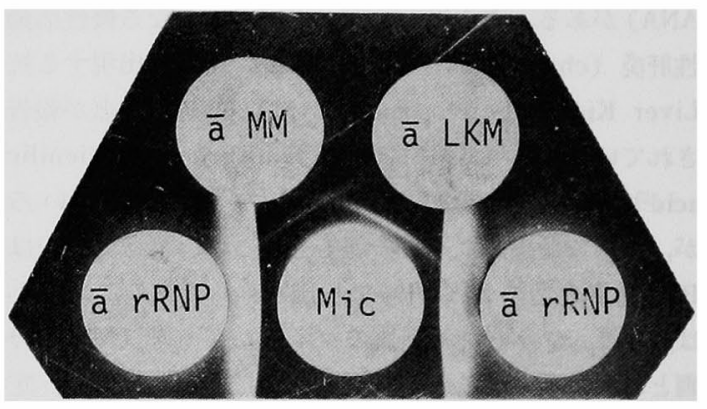

図 1 Double diffusion in agarose gel

The precipitin formed by MM antibody showed nonidentity with 2 other precipitins formed by anti-LKM antibody and anti-rRNP antibody.

表 1 Reactivity of MM antibody and two prototype sera against the cytoplasmic fraction of rat liver

\begin{tabular}{lccc}
\hline \multirow{2}{*}{ Prototype sera } & \multicolumn{3}{c}{ Antigen } \\
\cline { 2 - 4 } & Mitochondria & Microsome & Supernatant \\
\hline MM antibody & $(-)$ & $12.5 \mathrm{mg}^{*}$ & $25.0 \mathrm{mg}$ \\
Mitocondria antibody & $12.5 \mathrm{mg}$ & $(-)$ & $(-)$ \\
rRNP antibody** & $6.3 \mathrm{mg}$ & $1.6 \mathrm{mg}$ & $25.0 \mathrm{mg}$ \\
\hline
\end{tabular}

${ }^{*}$ Values refer to the lowest concentration of antigen for positive reaction

${ }^{* *}$ rRNP : ribosomal ribonucleoprotein 


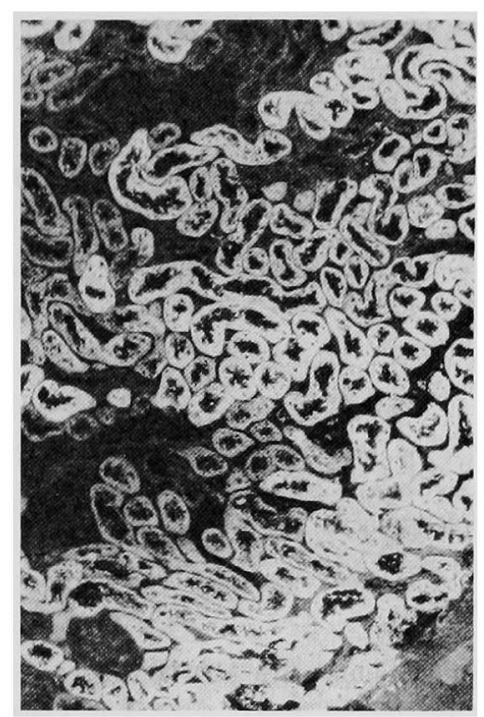

2-a : Rat kidney cortex treated with $1: 20$ diluted serum containing anti-liver kidney microsome antibody from patient with chronic active hepatitis was subsequently incubated with FITC-conjugated rabbit anti-human $\gamma$-globulin. The proximal tuble cytoplasm was uniformly stained. The distal tuble cytoplasm and mensenchymal cell cytoplasm were not stained $(\times 200)$.

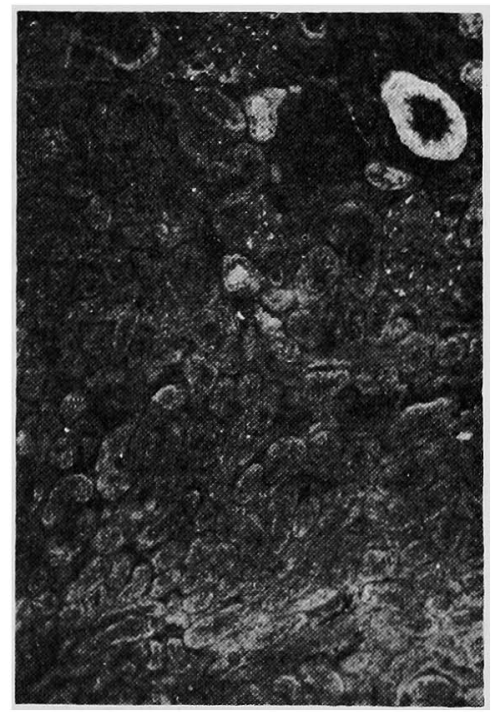

2-c : Rat kidney cortex treated with $1: 20$ diluted serum containing $\mathrm{MM}$ antibody from a patient with liver cirrhosis. Both proximal and distal tuble cytoplasm remained unstained $(\times 200)$.

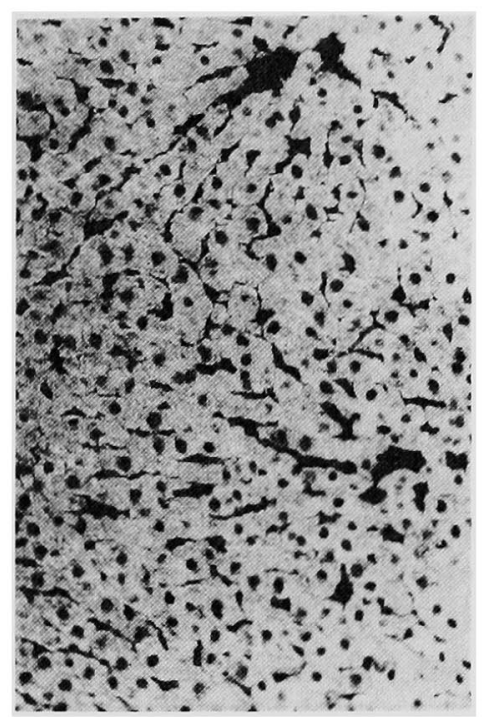

2-b : Rat liver treated as in 2-a.

Hepatocytes showed intense fine granular staining $(\times 400)$.

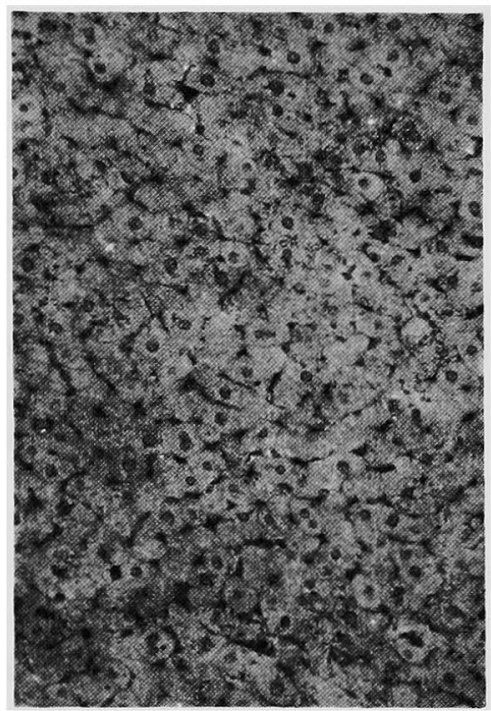

2- $\mathrm{d}$ : Rat liver treated as in 2-c.

Hepatocytes showed no staining . $(\times 400)$.

図 2 Immunofluorescent staining 
表 2 Incidence of the MM antibody in sera of patients with various liver diseases

\begin{tabular}{lccc}
\hline Disease & No of patients & No of positive & Positive percent \\
\hline PBC & 19 & 3 & $16 \%$ \\
PBC-CAH & 5 & 5 & $100 \%$ \\
CAH & 14 & 2 & $14 \%$ \\
CH & 11 & 0 & $0 \%$ \\
HCC & 3 & 0 & $0 \%$ \\
LC & 9 & 1 & $11 \%$ \\
AVH & 5 & 0 & $0 \%$ \\
Normal & 25 & 0 & $0 \%$ \\
\hline
\end{tabular}

$\mathrm{PBC}$ : primary biliary cirrhosis, $\mathrm{CAH}$ : chronic active hepatitis,

$\mathrm{CH}$ : chronic hepatitis, $\mathrm{HCC}$ : hepatic cell carcinoma,

LC : liver cirrhosis, AVH : acute viral hepatitis

表 3 Laboratory findings of 5 PBC-CAH overlap patients with $\mathrm{MM}$ antibody

\begin{tabular}{|c|c|c|c|c|c|c|c|c|c|c|c|c|c|c|c|c|c|c|c|}
\hline \multirow{2}{*}{ Group } & \multirow{2}{*}{ Name } & \multirow{2}{*}{ CNSDC } & \multirow{2}{*}{$\begin{array}{c}\text { ANA } \\
\text { IIF }\end{array}$} & \multirow{2}{*}{ pattern } & \multirow{2}{*}{$\begin{array}{c}\text { AMA } \\
\text { IIF }\end{array}$} & \multicolumn{3}{|c|}{ AMA (DID) } & \multirow{2}{*}{ other *** } & \multirow{2}{*}{$\begin{array}{l}\text { MM } \\
\text { titer }\end{array}$} & \multirow{2}{*}{$\operatorname{IgG}$} & \multirow{2}{*}{$\operatorname{Ig} A$} & \multirow{2}{*}{$\operatorname{IgM}$} & \multirow{2}{*}{ GOT } & \multirow{2}{*}{ GPT } & \multirow{2}{*}{ T.B. } & \multirow{2}{*}{ T.chol } & \multirow{2}{*}{$\begin{array}{c}\text { Alp } \\
\text { (K.A.) }\end{array}$} & \multirow{2}{*}{$\gamma$-GPT } \\
\hline & & & & & & $\mathrm{M}-\mathrm{A}$ & $M=B$ & $\mathrm{M}-\mathrm{C}$ & & & & & & & & & & & \\
\hline I & $\mathrm{MM}^{*}$ & + & - & & 1,280 & 16 & $>32$ & - & - & $1: 8$ & 1,679 & 819 & 1,068 & 157 & 124 & 8.4 & 354 & 67.6 & 426 \\
\hline \multirow[t]{3}{*}{ II } & $\mathrm{TT}$ & + & - & & 160 & - & 4 & - & 1 & $1: 16$ & 1,256 & 85 & $>400$ & 84 & 143 & 1.2 & 336 & 27.4 & 200 \\
\hline & $\mathrm{KN}$ & + & - & & 80 & 2 & 8 & - & - & $1: 4$ & 1,750 & 375 & $>400$ & 97 & 91 & 1.4 & 248 & 23.3 & 84 \\
\hline & YH & + & $>1,280$ & Centro. & 320 & - & 64 & - & - & $1: 1$ & 1,926 & 247 & 666 & 49 & 53 & 0.6 & 173 & 17.8 & 118 \\
\hline III & T S & + & 320 & Homo. & - & - & - & - & 1 & $1: 1$ & 2,619 & 388 & 139 & 39 & 20 & 0.2 & 170 & $1,155^{* *}$ & 266 \\
\hline
\end{tabular}

CNSDC : chronic non suppurative destructive cholangitis

ANA : anti-nuclear antibody

AMA : anti-mitochondrial antibody

Centro. : centromere

Homo. : homogeneous

*deceased **IU/1 ***unclassified precipitating AMA

\section{MM 抗体の疾患別出現頻度}

さまざな肝疾患の患者血清につき Mic 抗原との反 応をスクリーニング，同定し，その $\mathrm{MM}$ 抗体の陽性頻 度を求めた. PBC は 19 例中 3 例 (16\%), PBC-CAH は 5 例中 5 例 $(100 \%), \mathrm{CAH}$ は 14 例中 2 例 $(14 \%), \mathrm{LC}$ は 9 例中 1 例 (11\%) に陽性が認められた. しかし， $\mathrm{CH}$, HCC, AVH，正常人血清には MM 抗体は認められな かった (表 2).

\section{MM 抗体陽性 5 症例}

臨床症状，検查所見が十分に把握された 5 症例につき 所見をまとめた (表 3). 肝生検は 5 例中全例施行され, 病理組織学的に CNSDC があり, さらに CAH の像む呈 していた. MM 例は定型的 PBC-CAH 重複例で肝機能 異常が発見されてから 3 年目で死亡した. TT, KN, YH 例は CNSDC の所見は認められるが Alp も正常の上限 值の 3 倍以下であり，TT 例を除きコレステロールも正 常值であり, 定型的 PBC-CAH 重複症例でなく， II群
と分類した. TS 例は慢性関節リウマチがあり，5〜6年 後, 肝機能異常が発見されたが, IIF 法で AMA は陰性, DID 法で未同定の AMA が原血清で陽性であった. IgM も低值, T.B. は正常, コレステロールの上昇もなく而群 と分類した.

\section{IV. 考按}

PBC-CAH 重複症例に高頻度に出現するいまだ報告の ない MM 抗体を報告した. 本抗体はラット肝細胞質 3 分画を用いた DID 法で, Mit 分画と反応せず, Mic 分 画と強く反応した.

本抗体陽性の TF 血清はラット肝，腎を用いた IIF 法 では陰性であった.しかし，抗体価が低いことによる可 能性し否定できない.また，他の血清では共存する AMA のため, 判定できなかった.

Berg らは PBC のマーカー抗体と報告した抗 M2 抗

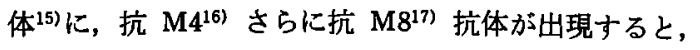
肝実質障害著明となり，予後不良であることを報告して 
いる. そこで，MM 抗体が Berg らの報告する抗 M4， 抗 M8 抗体との異同を検討するため, 本血清を Dr. Berg に送り，検討して戴いた，その結果，MM 抗体は 抗 M4，抗 M8 抗体とまったく異なるとの返事であった。 また, 抗 M4, 抗 M8 抗体はミトコンドリアの外膜に対 する抗体であり, しかも可溶性の蛋白ではなく, 当研究 所の超音波処理 Mit 分画を用いた DID 法では沈降抗 体は検出されなかった ${ }^{18)}$. それに反して, MM 抗体は AMA 検索用の Mit 分画とはまったく反応せず, 明ら 加 Mic 分画と反応し, 沈降抗体を形成し, 可溶性で ある点でも異なっていた. したがって，MM 抗体は抗 M4, 抗 M8 抗体とは異なるものであると考えられた. な⿰，本抗体は弱いながら Sup 分画とも反応し，抗原 の細胞内局在は明らかではない．

つぎに, MM 抗体の鑑別すべき抗体として, 1973 年, Rizzetto が報告した抗 LKM 抗体がある4,5). 抗 LKM 抗体は PBC 患者や，また ANA 陽性, ASMA 陽性の CAH (lupoid type) 患者血清中に㰸出されず, 1 つの CAH の subgroup の患者に出現することが報告されて いる19). しかし，MM 抗体は，PBC 患者血清の 20〜30\% に検出されること.また, 抗 LKM 抗体はラット肝細胞 質, ラット腎の近位尿細管細胞細胞質を染色する特徴を 認めるが, MM 抗体単独血清はいずれる特異染色しない こと.また，ラット肝の Mic 分画を用いた DID 法で， MM 抗体は抗 LKM 抗体の沈降抗体とは一致しないこ と. 以上の点から両者は異なるものであった.

本抗体陽性 PBC 例の一部は，早期より GOT, GPT や総ビリルビン值の上昇が著明であり，肝生検でグリン ン鞘の線維化著明と破罗の認められる $\mathrm{CAH}$ 像を呈した. なお, 腹腔鏡検查は 3 例に施行された. YH 例は肝表面 に結節像を認めたが, TT 例, TS 例には結節像は認め られなかった。

今回の報告では, $\mathrm{CAH}$ 症例 14 例中 2 例のみが, $\mathrm{MM}$ 抗体陽性を認めた.これらの症例は, ANA, ASMA 陽 性であり，本抗体は抗 LKM 抗体陽性の CAH とは異 なり, CAH (lupoid type) にも認められる抗体と考え られる.また, CAH (lupoid type) の重複例を含めた

1) Walker, J.G., Doniach, D., Roitt, I.M. et al. : Serological tests in diagnosis of primary biliary cirrhosis. Lancet, i : 827 831, 1965.

2) Doniach, D., Roitt, I.M., Walker, J.D. et al : Tissue antibodies in primary biliary cirrhosis,
PBC で MM 抗体陽性は 24 例中 8 例ほど認められたが， ASMA，ANA を有しているのは一部であり，MM 抗体 は ANA や ASMA との相関は考えられなかった.

Meyer zum Büschenfelde らは, 肝疾患患者血清中 に liver specific membrane lipoprotein (LSP) 抗体や liver membrane (LM) 抗体報告している ${ }^{20)}$. 抗 LSP 抗体は自己兔疫性肝疾患とされる PBC より自己免疫性

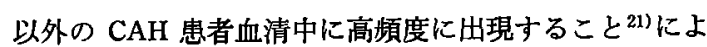
り $\mathrm{MM}$ 抗体とは異なると思われる. しかし，肝特異抗 原多数存在するものと考えられており ${ }^{22) ， こ れ ら の 1 ~}$ つと同じものである可能性も否定できない. 抗 LM 抗 体は辻らが報告しているごとく ${ }^{23)}, \mathrm{HBs}$ 抗体陽性のCAH やその他の自己免疫性肝疾患患者血清中にも高頻度にみ られるとの報告があり㘕別が必要と思われる。しかし， MM 抗体は Schneider らの方法で分画した Mic 分画 で容易に沈降抗体を証明できる点, MM 抗体陽性血清 （5 倍希釈）は肝細胞膜を螢光染色しない点で異なってい た.

当研究室では $\mathrm{PBC} の$ AMA を $\mathrm{M}-\mathrm{A}, \mathrm{M}-\mathrm{B}, \mathrm{M}-\mathrm{C}$, M-D の 4 種に分析 ${ }^{24 ~ 26)}$ ，その対応抗原を immunoblotting 27) や免疫電顕 ${ }^{18)}$ で検索してきた. しかし，これ らの抗体と PBC の臨林症状と病理組織像との相関は 明らかではない，今回の MM 抗体は現在までの検討で は，肝実質障害が著明で，肝生検で $\mathrm{CAH}$ との重複例と 考えられる患者に高頻度に出現していた.これまでの PBC の AMA の分析と MM 抗体の検索は, 自己免疫 性肝疾患の診断を容易にし, さらに PBC の病型ならび に予後に重要な手がかりとなる可能性がある. 今後症例 を積み重㸚て検討していく予定である.

\section{謝 辞}

本要旨は，第 31 回日本リウマチ学会総会 (東京) 扎よ び第 22 回日本肝歲学会東部会 (宇都宮) で報告した. 稿 を終えるにあたり，抗 LKM 抗体の標準血清を分与して 下さった Tübingen 大学, 教授 Dr. P.A. Berg ならび に Dr. E. Stechemesser に，また論文作成にあたり， 御協力戴いた R.W. Hankins, Ph. D. に感謝します.

献

active chronic (lupoid) hepatitis, cryptogenetic cirrhosis and other liver dise ases and their clinical implication. Clin. Exp. Immunol., 1 : 237 262, 1966.

3) Trenchev, P., Sneyd, P., Holborow, E.J. : Im- 
munofluorescent tracing of smooth muscle contractile protein antigens in tissues other than smooth muscle. Clin. Exp. Immunol., 16 : 125 136, 1974.

4) Rizzetto, M., Swana, G.T., Doniach, D. : Microsomal antibodies in active chronic hepatitis and other disorders. Clin. Exp. Immunol., 15 : 331 344, 1973.

5) Rizzetto, M., Bianchi, F.B., Doniach, D. : Characterization of the microsomal antigen related to a subclass of active chronic hepatitis. Immunology, $26: 589 \sim 601,1974$.

6) Smith, M.G.M., Williams, R., Walker, G. et al. : Hepatic disorders associated with liver kidney microsomal antibodies. Brit. Med. J., $2: 80 \sim 84,1974$.

7) Homberg, J.C., Andre, C., Abuaf, N. : A new anti-liver-kidney microsome antibody (antiLKM-2) in tienilic acid-induced hepatitis. Clin. Exp. Immunol., $55: 561 \sim 570,1984$.

8）佐々木 博・他：原発性胆汁性肝硬変, 全国調查 集計結果 (第 3 報), 厚生省特定疾患難治性の肝炎 調查研究班, 昭和 57 年度研究報告, pp. 102 .

9) De Groote, J., Desmet, V.J., Gedigk, P. et al. : A classification of chronic hepatitis. Lancet, ii : 626, 1968.

10) Popper, H., Schaffer, F. : Non suppurative destruction chronic cholangitis and chronic hepatitis. Progress in Liver Desease, vol. III, Edited by Popper, H. and Schaffner, F., Grune and Stratton, New York, 1970, pp. 336.

11) Sherlock, S. : Primary biliary cirrhosis. Pro gress in Liver Disease, vol. V, Edited by Popper, H. and Schaffner, F., Grune and Stratton, New York, 1976, pp. 559.

12) Schneider, W.C., Hogeboom, G.H. : Intracellular distribution of enzymes. V. Further studies on the distribution of cytochrome $c$ in rat liver homogenates. J. Biol. Chem., $183: 123 \sim$ $128,1950$.

13) Tan, E.M., Kunkel, H.G. : Characteristics of a soluble nuclear antigen precipitating with sera of patients with systemic lupus erythematosus. J. Immunol., $96: 464 \sim 471,1966$.

14) Lowry, O.H., Rosenbrough, N.H., Farr, A.I. et al. : Protein measurment with the Folin phenol reagent. J. Biol. Chem., 193 : 265 275, 1951.

15) Berg, P.A., Baum, H. : Serology of primary biliary cirrhosis. Spri. Semi. Immunopathol., $3: 355 \sim 373,1980$.

16) Berg, P.A., Klein, R., Lindenborn-Fotinos, J. et al. : Marker antigen for serological diagnosis of primary biliary cirrhosis. Lancet, ii : 1423 1425, 1982.

17) Berg, P.A., Weber, P., Oehring, J. et al. : Significance of different types of mitochondrial antibodies in primary biliary cirrhosis. Hepatology, Edited by Brunner, H. and Thaler, H., Raven Press, New York, 1985, pp. 231 242.

18）松嶋 広・宮地清光・和泉伸一・他 2 名: 抗ミ卜 コンドリア抗体の分類と免疫電顕法によるミトコ ンドリア内の対応抗原局在の研究. 臨床免疫, 印 刷中.

19) Manns, M., Meyer zum Buschenfelde, K.H., Slusarczyk, J. et al. : Detection of liver kidney microsomal autoantibodies by radioimmunoassay and their relation to anti-mitochondrial antibodies in inflammatory liver diseases. Clin. Exp. Immunol., $57: 600 \sim 608,1984$.

20) Mayer zum Buschenfelde, K.H., Miesher, P.A. : Liver specific antigens. Purification and characterization. Clin. Exp. Immunol., $10: 89 \sim 102$, 1972.

21) Kakumu, S., Arakawa, Y., Goji, H. et al. : Occurrence and significance of antibody to liverspecific membrane lipoprotein by double-antibody immunoprecipitation method in sera of patients with acute and chronic liver diseases. Gastroenterology, $76: 665 \sim 672,1979$.

22）森實敏夫 ·沢口健太郎 ·斉藤英胤 - 他 5 名 : モ， クローナル抗体によるヒト肝特異抗原の解析, 肝 胆膵, $13: 677 \sim 684,1986$.

23）辻 孝夫：肝細胞膜抗体. 肝胆膵, $11: 599 \sim 606$, 1985.

24) Miyachi, K., Gupta, R.C., Dickson, E.R. et al. : Precipitating antibodies to mitochondrial antigens in patients with primary biliary cirrhosis. Clin. Exp. Immunol., 39 : 599 606, 1980.

25) Miyachi, K., Watanabe, S., Yamashiki, M. et al. : Precipitating antimitochondrial antibodies 
in Japanese patients with primary biliary cirrhosis. Am. J. Gastro., 79 : 704 709, 1984.

26）神谷知至·本田孝也·鈴木 修-他 3 名：慢性甲 状腺炎, 慢性膵炎, Sicca 症候群を伴った原発性 胆汁性肝梗変の男性症例. 肝臟, $71: 759 \sim 765$,
1985.

27）松嶋 広・宮地清光・梃渡恒憲・他 2 名：抗ミ卜 コンドリア抗体の対応抗原の特性と精製. 日臨免 誌, $9: 487 \sim 475,1986$. 